\title{
CLINICOPATHOLOGICAL CHARACTERISTICS OF CA OESOPHAGUS - EXPERIENCE FROM A TERTIARY CARE CENTRE IN NORTH-EAST INDIA
}

\author{
Vikramjit Singha1, Sankari Roy² \\ ${ }^{1}$ Associate Professor, Department of ENT, Tripura Medical College. \\ ${ }^{2}$ Assistant Professor, Department of Anaesthesiology, Tripura Medical College.
}

\begin{tabular}{l}
\hline ABSTRACT \\
BACKGROUND \\
Ca oesophagus is one of the most serious tumours owing to its rapid development and fatal prognosis in most cases. Worldwide, \\
oesophageal cancer ranks eighth in cancer incidence and sixth in cancer mortality.
\end{tabular}

The objective was to study the patterns of involvement of Ca oesophagus.

\section{MATERIALS AND METHODS}

This study has been conducted in the Department of ENT in Tripura Medical College. Details of all the patients with Ca oesophagus who were admitted in the Department of ENT from June 2011 to May 2016 were collected from medical records department and analysed.

\section{RESULTS}

All the patients presented with progressive dysphagia and weight loss (100\%). Of all the patients, $63.2 \%, 34.5 \%$ and $24.1 \%$ patients presented with regurgitation, retrosternal pain and odynophagia respectively. The middle third of oesophagus was most frequently involved (59.8\%), followed by lower third (27.6\%) and upper third (12.6\%). HPE revealed squamous cell carcinoma in $88.5 \%$ and adenocarcinoma in $11.5 \%$ patients.

\section{CONCLUSION}

Oesophageal cancer is quite common in NE India. The peak age of presentation is in the sixth decade of life, and majority of patients present at advanced stage.

\section{KEYWORDS}

Ca Oesophagus, Squamous Cell Ca (SCC), Middle Third of Oesophagus.

HOW TO CITE THIS ARTICLE: Singha V, Roy S. Clinicopathological characteristics of Ca oesophagus - Experience from a tertiary care centre in North-East India. J. Evolution Med. Dent. Sci. 2016;5(99):7260-7262, DOI: 10.14260/jemds/2016/1642

\section{BACKGROUND}

Ca oesophagus is the sixth most common cause of cancer death worldwide and eighth in cancer incidence.1,2 Smoking and alcohol are two important and well known risk factors. The other risk factors are dietary deficiency, chronic irritation, achalasia, diverticulum. In China, Ca oesophagus is associated with diets that are contaminated with mycotoxins and low in antioxidants and micronutrients, whereas in the US tobacco and alcohol consumptions are major risk factors for oesophageal SCC.

The middle third of the oesophagus is the commonest site for SCC while the lower third is the commonest site for adenocarcinoma. ${ }^{3}$ Most patients present with dysphagia and weight loss. Mortality is very high as majority of patients report in advanced stage and even with operable tumours, postoperative mortality is about $50 \%{ }^{4}$

Financial or Other, Competing Interest: None.

Submission 03-11-2016, Peer Review 02-12-2016,

Acceptance 07-12-2016, Published 12-12-2016.

Corresponding Author:

Dr. Vikramjit Singha,

Associate Professor,

Department of ENT

Tripura Medical College \&

Dr. B. R. Ambedkar Memorial Teaching Hospital,

Hapania, Agartala-799014.

E-mail:vjtmc2011@gmail.com

DOI: $10.14260 /$ jemds $/ 2016 / 1642$

\section{(c) (i) $\$$}

The clinical stage of the disease at presentation is important for the outcome of the patients with Ca oesophagus. However, the outcome of treatment is poor in Tripura because majority of the patients report late, in whom only palliative care is possible.

\section{Objective of Study}

To study the patterns of involvement of Ca oesophagus.

\section{MATERIALS AND METHODS}

This study has been conducted in the Department of ENT in Tripura Medical College. Details of all the patients with $\mathrm{Ca}$ oesophagus who were admitted in the Department of ENT from June 2011 to May 2016 were collected. Data was retrieved from medical records department and analysed.

\section{Inclusion Criteria}

Patients with growth in the oesophagus and histopathologically confirmed cancer.

\section{Exclusion Criteria}

Histopathologically negative cases and unconfirmed cases.

\section{RESULTS}

During the period of study, a total of 87 cases of Ca oesophagus were registered. The age of patients at presentation ranged from 38 to 79 years. $22(25.3 \%)$ patients were aged 50 years or below and $65(74.7 \%)$ patients were above 50 years. Forty patients (45.9\%) belonged to 51-60 age group. There were 62 
(71.3\%) men and $25(28.7 \%)$ women with a male to female ratio of $2.5: 1$. Majority of the patients $(65.5 \%)$ belonged to rural areas and $72.4 \%$ patients were from low socioeconomic group.

All the patients presented with progressive dysphagia and weight loss (100\%). 55 (63.2\%), 30 (34.5\%) and 21 (24.1\%) patients presented with regurgitation, retrosternal pain and odynophagia respectively. Smoking and alcohol consumption were revealed by $60(68.9 \%)$ and $55(63.2 \%)$ patients respectively. Family history of oesophageal cancer was reported by 22 (25.3\%) patients.

The middle third of the oesophagus was most frequently involved (59.8\%), followed by lower third (27.6\%) and upper third $(12.6 \%)$. On oesophagoscopic examination, majority of the lesions were ulcerative (52.9\%). HPE revealed squamous cell carcinoma in majority of the patients $(88.5 \%)$. Adenocarcinoma occurred in $10(11.5 \%)$ cases. Of all adenocarcinoma cases, $8(80 \%)$ cases involved lower third and $2(20 \%)$ cases involved middle third of oesophagus. TNM staging was done in 66 patients, out of which $81.4 \%$ patients were in advanced stage (Stages III and IV).

\begin{tabular}{|c|c|c|}
\hline Variables & $\begin{array}{c}\text { Number } \\
\text { of Patients }\end{array}$ & $\mathbf{\%}$ \\
\hline Age (in years) & & \\
\hline$\leq 50$ & 22 & $25.3 \%$ \\
\hline$>50$ & 65 & $74.7 \%$ \\
\hline Gender & & \\
\hline Male & 62 & $71.3 \%$ \\
\hline Female & 25 & $28.7 \%$ \\
\hline Area of Residence & 30 & $34.5 \%$ \\
\hline Urban & 57 & $65.5 \%$ \\
\hline Rural & 63 & $72.4 \%$ \\
\hline Socioeconomic Status & 24 & $27.6 \%$ \\
\hline Low & & \\
\hline High & 60 & $68.9 \%$ \\
\hline Smoking & 27 & $31.1 \%$ \\
\hline Yes & & \\
\hline No & 55 & $63.2 \%$ \\
\hline Alcohol Consumption & 32 & $36.8 \%$ \\
\hline Yes & & \\
\hline No & 16 & $18.4 \%$ \\
\hline Family History of \\
Ca Oesophagus & & $81.6 \%$ \\
\hline Yes & & \\
\hline No & & \\
\hline Table 1. Distribution of Patients \\
\hline \multicolumn{2}{|c|}{} \\
\hline According to their Features \\
\hline
\end{tabular}

\begin{tabular}{|c|c|c|}
\hline Variables & Frequency & Percentage \\
\hline Site & & \\
\hline Upper Third & 11 & $12.6 \%$ \\
\hline Middle Third & 52 & $59.8 \%$ \\
\hline Lower Third & 24 & $27.6 \%$ \\
\hline Gross Appearance & & \\
\hline Ulcerative & 46 & $52.9 \%$ \\
\hline Infiltrative & 22 & $25.3 \%$ \\
\hline Proliferative & 19 & $21.8 \%$ \\
\hline Histological Types & & \\
\hline SCC, Well Differentiated & 21 & $24.1 \%$ \\
\hline
\end{tabular}

\begin{tabular}{|c|c|c|}
\hline SCC, Mod. Differentiated & 39 & $44.8 \%$ \\
\hline SCC, Poorly Differentiated & 17 & $19.5 \%$ \\
\hline Adenocarcinoma & 10 & $11.5 \%$ \\
\hline Tumour Staging & & \\
\hline I, II & 19 & $21.8 \%$ \\
\hline III, IV & 47 & $54.02 \%$ \\
\hline Not Documented & 21 & $24.1 \%$ \\
\hline
\end{tabular}

\section{DISCUSSION}

Oesophageal cancer is one of the most serious tumours, owing to its rapid development and fatal prognosis in most cases. Worldwide, oesophageal cancer ranks eighth in cancer incidence and sixth in cancer mortality. The incidence of oesophageal cancer varies widely, and certain areas such as northern China, north-eastern Iran and South Africa have very high rates of this disease with age standardised incidence rates from 50 to over 100 cases per 100,000 population per year.

In a study by Mabula D Mchembe et al in Tanzania, the peak age of incidence of oesophageal cancer in this study was found to be in the fourth decade of life, which is about a decade or two earlier compared to the findings in developed countries. ${ }^{5}$ In our study, the peak age of incidence was found to be in the sixth decade of life.

The male predominance demonstrated by Mabula D Mchembe et $\mathrm{al}^{5}$ in their study was in keeping with previous observation reported in a study performed elsewhere. However, equal gender distribution was reported in previous studies from Nigeria and Kenya.6,7 In our study, male: female ratio was $2.5: 1$. The male predominance in our study can be explained by the fact that most of known risk factors of oesophageal cancer are related to behaviour- smoking and excessive alcohol consumption- of which men are known to be worst consumers than their gender counterparts.

Globally, oesophageal cancer has been reported to be more prevalent in people with low socioeconomic status. ${ }^{8}$ This observation is reported in our study where $72.8 \%$ of patients were from low socioeconomic group. Socioeconomic class appears to be an independent risk factor in the development of oesophageal cancer. The vast majority of patients (65.5\%) in the present study came from the rural areas. A similar observation was reported by others.

Several risk factors have been implicated in the geographic variation in the incidence of oesophageal cancer, ${ }^{9,10}$ Alcohol and tobacco abuse in the aetiology of oesophageal cancer is well established. In our study, history of alcohol consumption and smoking was documented in $63.2 \%$ and $68.9 \%$ of patients respectively. It has been estimated that more than $80 \%$ of oesophageal cancer cases in industrialised countries can be attributed to exposure to these lifestyle choices, either singly or jointly. Substantial alcohol intake, especially in combination with smoking, greatly increases the risk of squamous-cell carcinoma but not adenocarcinoma. The joint effect of alcohol and smoking when consumed together are potentiated and the final relative risk is multiplied.

Family history of oesophageal cancer has also been shown to be relevant in some high-risk areas. A study in Shanxi province, China, found that families who have a prior history of oesophageal cancer were significantly more likely to have reported as new case during 10 years of followup. In the present study, family history of oesophageal cancer was 
reported in $18.4 \%$ cases, a figure significantly lower than the $43 \%$ reported by Dawsey et al.

The two most common symptoms present in all our patients were dysphagia and weight loss which is similar to previous studies from within and outside Africa. In this study, all patients presented at an advanced stage with progressive dysphagia and weight loss. Dysphagia and weight loss are so commonly associated that some authors regard them as being pathognomonic. Dysphagia is usually associated with bulky tumours that obstruct the oesophageal lumen, impairing its function and causing pain.

The location of the tumour within the length of the oesophagus varies with the histological type. Squamous cell carcinoma is commonly found in the middle and distal third of the oesophagus while adenocarcinoma is more commonly located in the distal third.

\section{CONCLUSIONS}

Oesophageal cancer is quite common in this part of India. The peak age of presentation is in the sixth decade of life and majority of patients present at advanced stage. Majority of the patients were from rural areas and belonged to low socioeconomic group. In our study, majority of the cases involved the middle third of oesophagus and most of the cases were squamous cell carcinomas. Poor accessibility to healthcare, lack of awareness, lack of screening programmes are reasons why majority of patients present in advanced stage.

\section{REFERENCES}

1. Jernal A, Murray T, Samuels A. Cancer statistics, 2003. CA Cancer J Clin 2003;53(1):5-26.

2. Parkin DM, Bray F, Ferlay J. Global Cancer statistics, 2002. CA Cancer J Clin 2005;55(2):74-108.

3. Schlansky B, Dimarino AJ, Loren D. A survey of oesophageal cancer: pathology, stage and clinical presentation. Aliment Phamacol Ther 2006;23(5):58793.

4. Adegboye VO, Obajimi MO, Ogunseyinde AO, et al. Transhiatal oesophagectomy as palliative treatment for carcinoma of the oesophagus. East Afr Med J 2002;79(6):311-6.

5. Mchembe MD, Rambau PF, Chalya PL, et al. Endoscopic and clinicopathological patterns of esophageal cancer in Tanzania: experiences from two tertiary health institutions. World J Sug Oncol 2013;11:257-63.

6. Pindiga HU, Akang EE, Thomas JO, et al. Carcinoma of the oesophagus in Ibadan. East Afr Med 1997;74(5):307-10.

7. Wakhisi J, Patel K, Buziba N, et al. Esophageal cancer in north rift valley of western Kenya. Afr Health Sci 2005;5(2):157-63.

8. Kollarova H, Machova L, Horakova D, et al. Epidemiology of esophageal cancer--an overview article. Biomed Pap Fac Univ Palacky Oiomouc Czech Repub 2007;151(1):1720.

9. Walker AR, Adam F, Walker J, et al. Cancer of the oesophagus in Africans in sub-Saharan Africa: any hopes for its control? Eur J Cancer Prev 2002;11(5):413-8.

10. Vizcaino AP, Parkin DM, Skinner ME. Risk factors associated with oesophageal cancer in Bulawayo, Zimbabwe. Br J Cancer 1995;72(3):769-73. 